\title{
The Porretta thermal springs (Northern Apennines): seismogenic structures and long-term geochemical monitoring
}

\author{
Nicola Ciancabilla $\left({ }^{1}\right)$, Manuela Ditta $\left({ }^{2}\right)$, Francesco Italiano $\left({ }^{2}\right)$ and Giovanni Martinelli $\left({ }^{3}\right)$ \\ (1) Agenzia Regionale Prevenzione e Ambiente (ARPA) dell'Emilia Romagna, Sezione di Bologna, Italy \\ (2) Istituto Nazionale di Geofisica e Vulcanologia, Sezione Palermo, Italy \\ ( $\left.{ }^{3}\right)$ Agenzia Regionale Prevenzione e Ambiente (ARPA) dell'Emilia Romagna, Sezione di Reggio Emilia, Italy
}

\begin{abstract}
The thermal springs of Porretta are located on a seismically active area of the Northern Apennines. In 19th Century a chemist identified anomalous behaviour of the thermal waters in concomitance with local seismic events. Recent studies assessed the geochemical features of the circulating fluids (e.g., waters carry a dissolved $\mathrm{CH}_{4}$-dominated gas phase with a radiogenic signature of the helium isotopic ratio) and observed anomalous hydrologic and geochemical signals possibly related to crustal strain phenomena due to local seismic events. Long-term geochemical monitoring was carried out from 2001 to 2006 with the aim of detecting the behaviour of the circulating fluids possibly coinciding with seismic activity. The collected data reveal a sensitivity of the thermal waters to the activity of the main fault crossing the village of Porretta and identify a «seismogenic» structure crossing the village.
\end{abstract}

Key words geochemical monitoring - seismicity tectonic lines

\section{Introduction}

The thermal springs of Porretta are located in the Northern Apennines over an area crossed by several tectonic lineaments (fig. 1). The thermal waters have been locally utilized for medical purposes since the Etruscan age. A large scientific literature on the therapeutic characteristics of Porretta thermal waters has been written during the past five centuries and many observational data were recorded. In particular Capponi (1608) noted that «after five local seismic events water flow-rate increased up to four times more than

Mailing address: Dr. Manuela Ditta, Istituto Nazionale di Geofisica e Vulcanologia, Sezione Palermo, Via Ugo La Malfa 153, Palermo, Italy; e-mail: m.ditta@pa.ingv.it usual and their temperature was too hot to touch with the hands». Post seismic thermal and flow rate anomalies were also detected on April 20, 1765, April 11, 1787, June 10, 1904, December 28, 1908, June 5, 1910 and July 24, 1911 together with anomalies in methane gas bubbling and in local methane dry gas emissions (Facci et al., 1995). Demetrio Lorenzini, a local chemist who utilized cold groundwaters and thermal waters for chemical preparations, observed water flow rate and temperature anomalies in concomitance with a local seismic event in 1872 (Lorenzini, 1898). Lorenzini monitored water level fluctuations in a drilled well close to the thermal springs in the period 1873-1882 to study possible seismic precursors in cooperation with M.S. De Rossi (De Rossi, 1875).

He observed that in concomitance with local seismic events a water level decrease in a local well accompanied a flow rate increase of the thermal springs. A detailed statistical processing of the available data recorded by Lorenzini was carried out by Albarello et al. (1991) revealing 

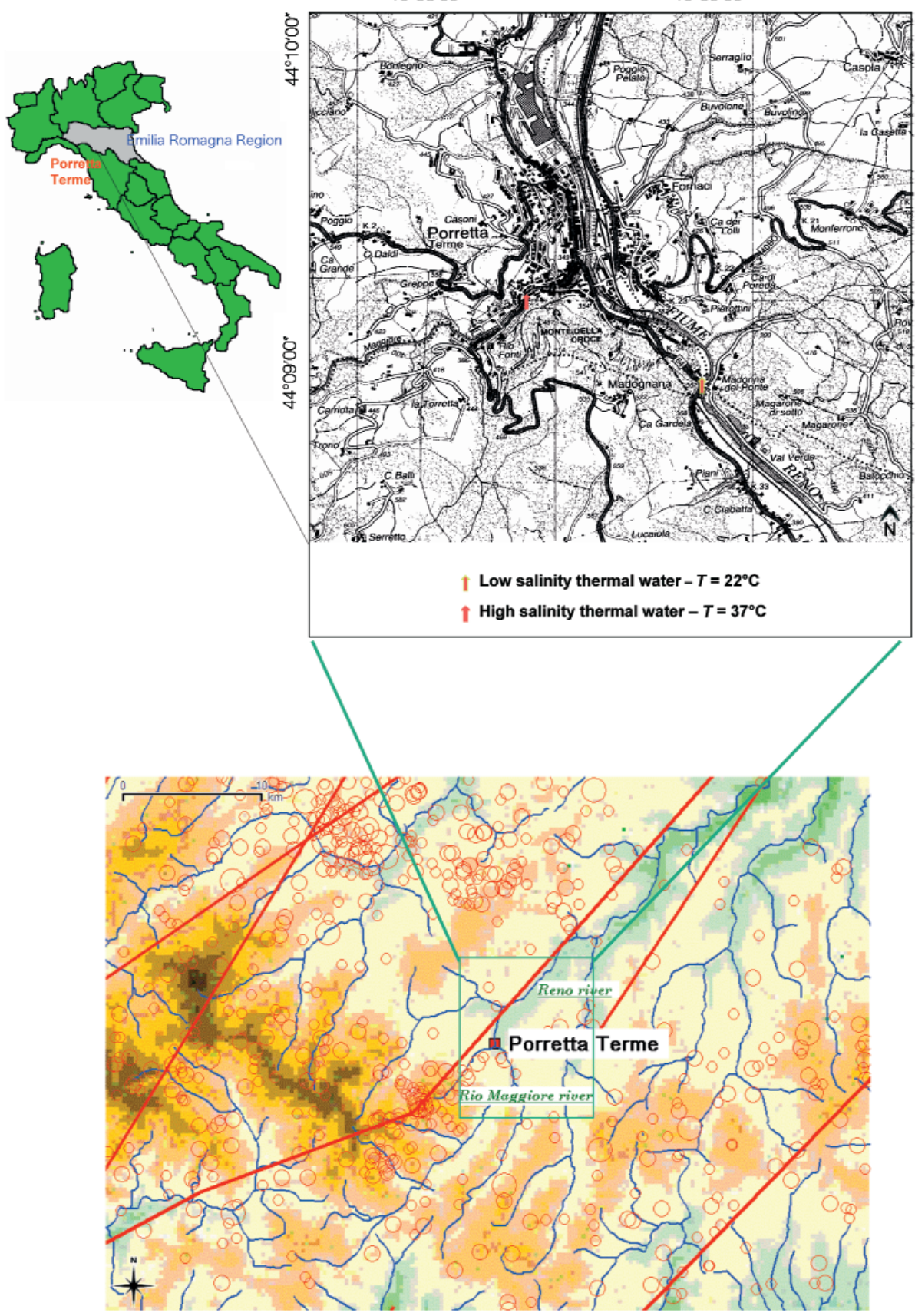

Fig. 1. Location of the investigated area on the Northern Apennines and the recognized tectonic structures (after biblio). The earthquakes that hit the area from 1980 to 2002 (Castello et al., 2005) and the recent 2003-2005 events are also plotted. It is easy to observe an high density of events on the tectonic line crossing Porretta Terme. 
possible precursory beaviours of water level fluctuations. After a local $M_{w}=5.3$ seismic event in 2003 (Seismic Bulletin, 2007) whose epicentre was located close to the village of Monghidoro about $25 \mathrm{~km}$ to the East of Porretta Terme, significant anomalies in temperature, flow rate and bubbling gas emissions were recorded both by visual observations and direct measurements. To better understand possible relations among local seismicity and hydrogeochemical patterns of Porretta thermal springs a geochemical prospection and a continuous monitoring program were carried out. This paper deals with the main results obtained from the collected geochemical data focussing on the relationship between fluids and tectonic structures.

\section{Study sites and geological background}

The thermal manifestations located in the Porretta area are caracterized by spontaneous spillage of about ten springs inside the town (fig. 1). Among those, five springs named Bove, Marte, Donzelle, Leone and Sale, are located to the southwest where the old hotel of the Thermal baths is located (fig. 2). The water temperature ranges from $34^{\circ} \mathrm{C}$ to $37^{\circ} \mathrm{C}$; they are salty waters enriched in bromium and iodine ions and characterized by a methane-dominated dissolved gas phase.

The other springs named Puzzola 1, Puzzola 2, Porretta Nuova, Porretta Vecchia and Majocchi, are spread in proximity of the Reno River 1 $\mathrm{km}$ from the thermal baths. They are also salsobromoiodine waters with bubbling and dissolved $\mathrm{CH}_{4}$-dominated gases, with lower temperature $\left(20-26^{\circ} \mathrm{C}\right)$ and salinity compared to the above mentioned springs (Ciancabilla et al., 2004).

Water and gas samples were collected at Porretta Nuova, Puzzola 1, Bove and Sale springs to investigate the Porretta thermal system; the selected springs are considered the most representative of the whole thermal system.

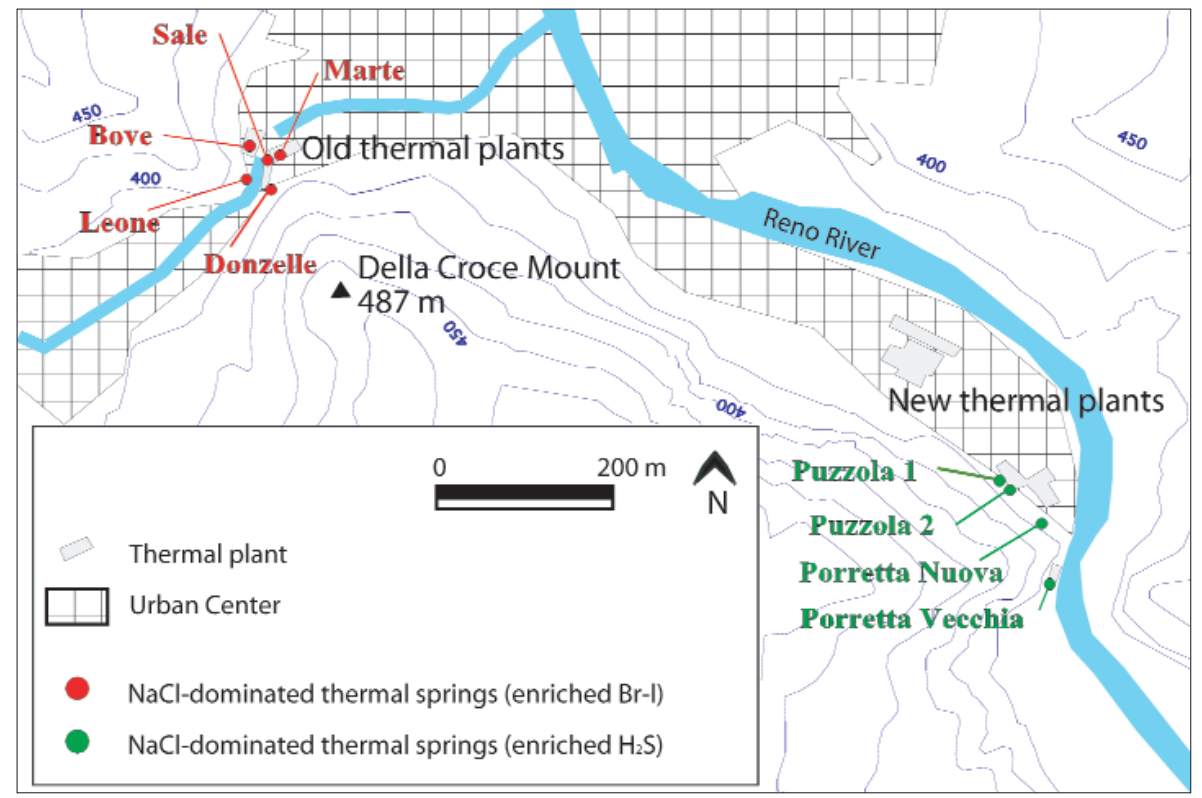

Fig. 2. Sampling sites at Porretta thermal area. The thermal waters are close to the old and new thermal plants respectively located on the Rio Maggiore and Reno rivers. 


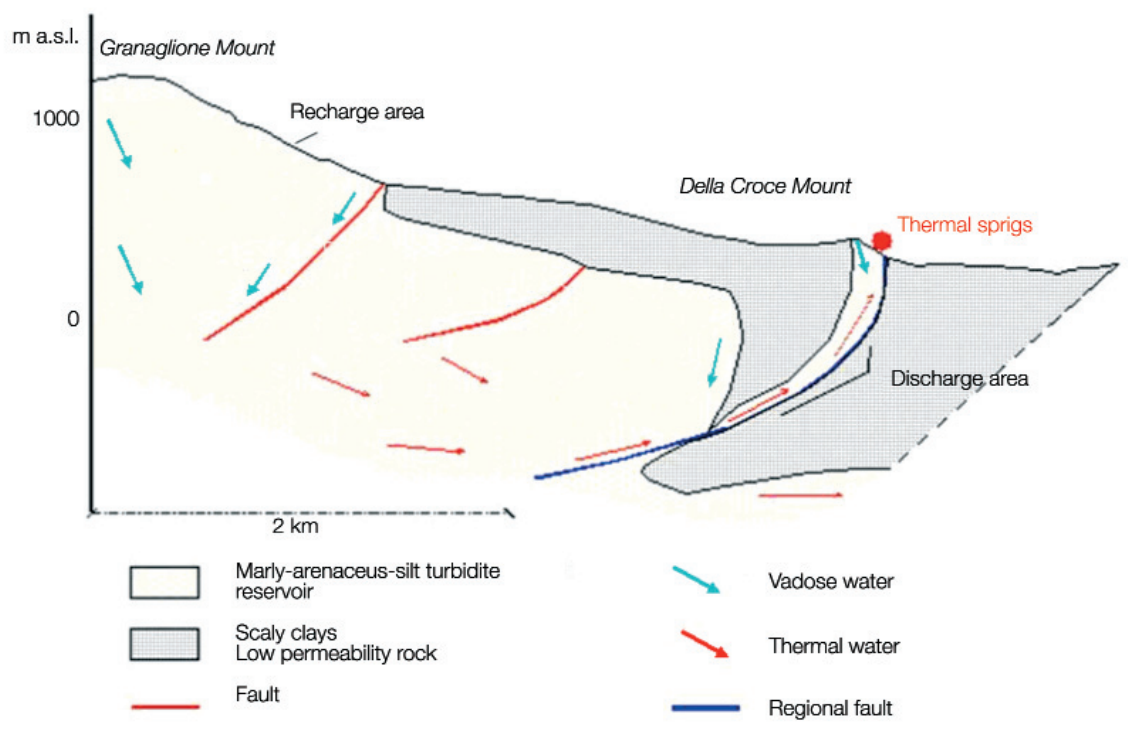

Fig. 3. Schematic section showing the recharge area/thermal springs relative positions and the main structures governing the groundwater circulation through the different lithotypes.

\subsection{Geology and tectonic setting}

The Northern Apennines are a NE-verging thrust and fold belt characterized by a crustal extension of about $2.5 \mathrm{~mm} / \mathrm{yr}$ and by moderate and large normal faulting seismic events (Hunstad et al., 2003; Chiaraluce et al., 2004). The extension along NW-trending faults is balanced by compressive trends recognized in the nearby Po Valley area (Montone et al., 2004). Tectonic processes are accomodated by complex mechanisms on pre-existing structures. While the extension along the Apenninic belt is related to the Adriatic lithosphere retreat, compressive trends are probably related to subordinate processes (Piccinini et al., 2006). No significant historical earthquakes are reported in the Porretta Terme area but evidence for widespread low-slip Quaternary faulting along the entire length of the Reno River were recently obtained by detailed strata terraces analysis (Bierma et al., 2005). Local seismicity is characterized by relatively frequent low magnitude events consistent with a low-slip Quaternary faulting.
The village of Porretta Terme is located at the confluence of the Rio Maggiore and the Reno rivers, over a land that is mostly made up of a formation of so-called scaly clays (Palombini shales), close to a large formation of marly-arenaceus and calcarenitic turbidite. The geologic setting in the high Reno valley area, where the thermal sources of Porretta are located, is characterized by two main rock formations: the Tuscan units, characterized by litic arenaceus silt formations (Porretta, Macigno and Cervarola formations) and the Ligurian units, made by clays and strongly fossilized shales with rocky mass characterized by different nature and size. The geologic structure of the over said units is to be tied up to the contraction (middle Cretaceous) and to the closing (middle Eocene) of the Piemonte-Ligurian ocean (located between the African and the European plate). The compressive stress pushed and crossed over (Oligo-Miocene) the Cretaceous Eocene formations (Ligurian facies) on the Triassic-Oligocene formations (Tuscan facies), then everything was pushed as a wave through East shaping folds and overlaps (Duchi et al., 2005). From a geologic point of view the Porret- 
ta area consists of an anticlinal fold with the nucleus made by Oligo-Miocene «Macigno» sediment. The northern side of the fold is vertical and the southern side goes down toward SW through a series of fold and faults with anti Appennine direction and other one with sub-vertical immersion and orthogonal to the first (Bencini and Duchi, 1980). The turbidite formations (Tuscan Units) represent the recharge basin for the investigated springs (Cianciabilla et al., 2004 and references therein). In particular the water discharge in Porretta baths crosses the Porretta Formation (a sand-silt grain stone entirely similar to the rock in feeding area) and rises to the surface through a deep regional tectonic dislocation (fig. 3). The Porretta Formation acts as a natural draining wedge in a low permeability setting (sandstone unities). It connects the warm overpressure waters accumulated in depth to the external environment with its stratification joints and fractures.

\section{Sampling and analytical procedures}

Samples of thermal waters, dissolved and bubbling gases were collected to be analyzed for their chemical and isotopic composition. Water temperature, $\mathrm{pH}$ value and electrical conductivity were measured directly in the field. The water samples were analyzed for major and minor elements by ion chromatography (Dio-nex DX-120 equipped by Dionex CS12A and AS14A columns, reproducibility within $\pm 2 \%$ ). The $\mathrm{HCO}_{3}$ amount was measured by volumetric titration with $0.1 \mathrm{~N} \mathrm{HCl}$. Mass spectrometric analyses were carried out by a Finnigan Delta ${ }^{\text {Plus }} \mathrm{XP}$ and by an Analitical Precision 2003 mass spectrometers respectively for $\mathrm{D} / \mathrm{H}$ and for the $\delta^{18} \mathrm{O}$ isotopic ratios. D/H isotopic analyses of water were performed using the Kendall and Coplen (1995) technique (reaction with $\mathrm{Zn}$ at $450^{\circ} \mathrm{C}$ ), while ${ }^{18} \mathrm{O} /{ }^{16} \mathrm{O}$ analysis were carried out by the $\mathrm{CO}_{2}$-wa-

Table I. Chemical composition of the sampled thermal waters. Concentrations in meq/l; TDS in mg/l. EC= $=$ electrical conductivity in $\mathrm{mS} / \mathrm{cm}$ at $20^{\circ} \mathrm{C}$. The isotopic composition of deuterium and oxygen are reported in $\delta$ unit per mil versus V-SMOW standard.

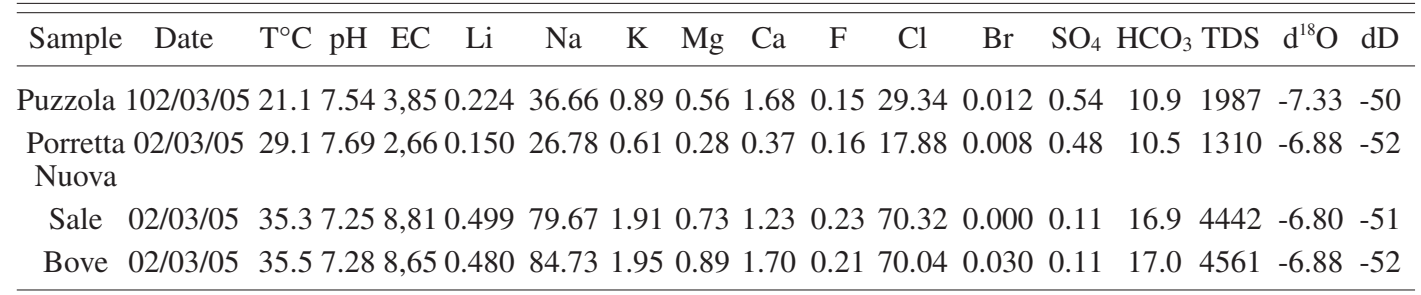

Table II. Analytical results for dissolved and bubbling gases. Dissolved gas data in cc/STP per litre; bubbling gas data in vol\% for $\mathrm{O}_{2}, \mathrm{~N}_{2}, \mathrm{CH}_{4}$ and $\mathrm{CO}_{2}$, in ppm for $\mathrm{He}$ and $\mathrm{H}_{2}$.

\begin{tabular}{cccccccccccc}
\hline $\begin{array}{c}\text { Dissolved gas } \\
\text { sample }\end{array}$ & Date & $\mathrm{He}$ & $\mathrm{H}_{2}$ & $\mathrm{O}_{2}$ & $\mathrm{~N}_{2}$ & $\mathrm{CO}$ & $\mathrm{CH}_{4}$ & $\mathrm{CO}_{2}$ & $\mathrm{R} / \mathrm{Ra}$ & $\mathrm{He} / \mathrm{Ne}$ \\
\hline Puzzola1 & $02 / 03 / 2005$ & $<$ & $<$ & 0.05 & 1.7 & $8.68 \mathrm{E}-05$ & $3.52 \mathrm{E}+01$ & 10.7 & n.a. & n.a. \\
Bove & $02 / 03 / 2005$ & $<$ & $<$ & 0.07 & 1.2 & $1.53 \mathrm{E}-04$ & $4.94 \mathrm{E}+01$ & 29.6 & n.a. & n.a. \\
$\begin{array}{c}\text { Porretta Nuova } \\
\text { Sale }\end{array}$ & $02 / 03 / 2005$ & $<$ & $2.0 \mathrm{E}-03$ & 0.05 & 2.1 & $3.74 \mathrm{E}-05$ & $3.15 \mathrm{E}+01$ & 6.2 & n.a. & n.a. \\
& $02 / 03 / 2005$ & $<$ & $<$ & 0.04 & 2.4 & $7.49 \mathrm{E}-05$ & $2.80 \mathrm{E}+01$ & 22.9 & n.a. & n.a. \\
\hline $\begin{array}{c}\text { Bubbling gas } \\
\text { sample }\end{array}$ & Date & $\mathrm{He}$ & $\mathrm{H}_{2}$ & $\mathrm{O}_{2}$ & $\mathrm{~N}_{2}$ & $\mathrm{CO}$ & $\mathrm{CH}_{4}$ & $\mathrm{CO}_{2}$ & $\mathrm{R} / \mathrm{Ra}$ & $\mathrm{He} / \mathrm{Ne}$ \\
\hline $\begin{array}{c}\text { Porretta Nuova } \\
\text { Sale }\end{array}$ & $02 / 03 / 2005$ & 25 & $<$ & $<$ & 11.1 & $<$ & 88.0 & 0.9 & 0.04 & 8.28 \\
\hline
\end{tabular}


ter equilibration technique (Epstein and Mayeda, 1953). The results are reported in \%o per mil units versus the V-SMOW standard. The standard deviations of measurements are approximately $\pm 1 \%$ for $\mathrm{D} / \mathrm{H}$ and $\pm 0.2 \%$ for the ${ }^{18} \mathrm{O} /{ }^{16} \mathrm{O}$.

The chemical composition of the dissolved and bubbling gases was determined by gaschromatography by a Perkin Elmer Autosystem XL gas chromatograph equipped with a $4 \mathrm{~m}$ Carboxen 1000 column, using Ar carrier and a double detector (HWD and FID Detectors). The detection limits are 2 ppmv for $\mathrm{He}$ and $\mathrm{H}_{2}, 1$ pp$\mathrm{mv}$ for $\mathrm{CH}_{4}$ and $\mathrm{CO}_{2}$ and $500 \mathrm{ppm}$ vol. for $\mathrm{N}_{2}$ and $\mathrm{O}_{2}$. The analytical error is $\pm 5 \%$ for $\mathrm{He}$, and $\pm 3 \%$ for the other gaseous species. The dissolved gases were extracted following the method proposed by Capasso and Inguaggiato (1998). Helium was purified in an ultra high vacuum line for helium isotope analyses following standard procedures (Italiano et al., 2004). The He to Ne ratio was measured by an in-line quadrupole mass spectrometer (QMS, VG Quartz). The isotopic analyses of the purified helium fraction were performed by a modified static vacuum mass spectrometer (VG5400TFT, VG Isotopes) that allows for the concomitant detection of ${ }^{3} \mathrm{He}$ and ${ }^{4} \mathrm{He}$-ion beams, reducing the ${ }^{3} \mathrm{He} /{ }^{4} \mathrm{He}$ measurement error to very low values. Typical uncertainties in the range of low- ${ }^{3} \mathrm{He}$ (radiogenic) samples are below $\pm 5 \%$. The analytical results are listed in tables I-II.

\subsection{Continuous monitoring}

Following tales and visual observations reported by local inhabitants, we found out that the thermal springs of Porretta Terme have undergone changes coinciding with seismic activity. Variations in water level, gas bubbling, turbidity etc. are the most common reported features. To better understand the possible effects of seismicity on the Porretta Terme thermal waters, a multiparameter device (Green-span CTD 350 Sensor) was installed at the Puzzola1 spring (in 2001, in 2004 and in 2006 respectively) and one more probe was installed in the Bove thermal spring $\left(T \cong 35^{\circ} \mathrm{C}\right)$ to monitor warmer water probably of deeper origin (from July 2004 to
March 2005). The probes provided conductivity, temperature and pressure data with an accuracy of $\pm 0.2 \% \mathrm{FS}, \pm 0.1{ }^{\circ} \mathrm{C}, 0,02 \% \mathrm{FS}$, respectively ( $\mathrm{FS}=$ full scale). The aim of the continuous monitoring activity was also to detect the possible man-induced noise to discriminate natural-induced signals from artifacts.

\section{Results and discussion}

\subsection{Chemical composition of the thermal waters}

All the sampled waters show a Cl-alkaly and a Na-dominated chemical signature, however a remarkable difference in salinity, 1300 and 4600mg/l and conductivity, $2600 \mu \mathrm{S}$ and $8600 \mu \mathrm{S}$, marked the two groups of thermal springs from the new and old thermal plants respectively (fig. 2). The triangular diagrams in fig. 4 display the alkali enrichment of the water springs feeding the Porretta Terme system. The lower $\mathrm{Cl}$ and $\mathrm{Na}$ contents of Porretta nuova and Puzzola 1 samples (fig. 5) are interpreted as a dilution process by parent waters of which the Sale and Bove springs represent the high salinity components. It may be the result of a mixing process between shallow meteoric waters and groundwaters which rise up through the main lithological contact or through tectonic alignments. The $\delta^{18} \mathrm{O}$ values reveal a meteoric origin of thermal springs (Minissale et al., 2000), infiltrating through local arenaceous rocks of «Macigno» and «Porretta» formations and temperatures consistent with a source of the main aquifer at a depth of about $1 \mathrm{~km}$.

Figure 5 shows the clear $\mathrm{Na}$ and $\mathrm{Cl}$ enrichment that induces $\mathrm{Na} / \mathrm{Cl}$ ratios well above the stoichiometric ratio of sea-water. A groundwaters halite interaction process cannot explain a $\mathrm{Na}$ abundance as high as $1950 \mathrm{mg} / \mathrm{l}$. Since the springs are also enriched in other alkaline elements (fig. 6), an interaction with clay layers where large cationic Na-Mg exchange occurs can be considered (Shoeller, 1955). According to Nanni and Zuppi (1986), salty waters are the expression of a mixing process between waters of meteoric origin and trapped brines inside the Neogenic marine sediments underlyng the lig- 


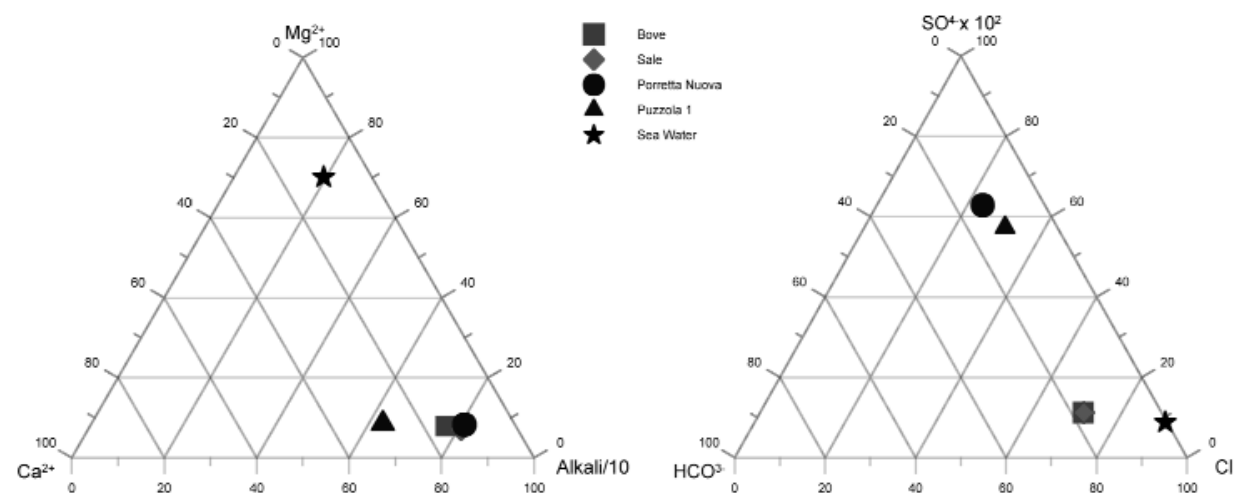

Fig. 4a,b. Ternary plot a) Ca-Mg-Alkali and b) $\mathrm{HCO}_{3}-\mathrm{Cl}_{-}-\mathrm{SO}_{4}$. The triangular diagrams display the composition of four main springs of Porretta Terme plant. All the samples are enriched in alkali element with high $\mathrm{Cl}$ content.
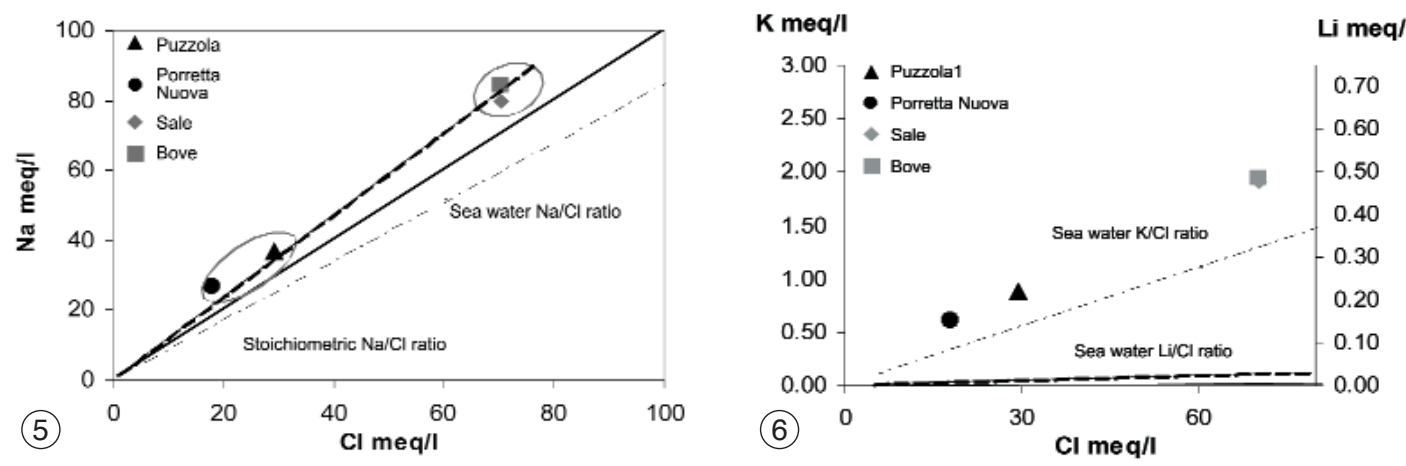

Fig. 5. meq/l Na versus meq/l $\mathrm{Cl}$ diagram. The figure distinguishes two water groups: Puzzola 1 and Porretta Nuova, marked by lower salinity and Bove and Sale springs characterized by higher concentrations. The Porretta Nuova and Puzzola1 samples represent the more diluted terms of a hypothetical mixing between a meteoric and a groundwater terms (dashed line) in the Porretta thermal system. All the samples are Na-enriched with respect to the stochiometric $\mathrm{Na} / \mathrm{Cl}$ ratio and the $\mathrm{Na} / \mathrm{Cl}$ ratio of seawater (black and dash-dot line respectively).

Fig. 6. meq/l $\mathrm{K}$ versus meq/l $\mathrm{Cl}$ and meq/l Li versus meq/l $\mathrm{Cl}$ concentration at the Porretta terme springs showing the enrichment in alkaline elements with respect to sea water.

urean allochthonous flysh. The brines would be squeezed and pushed toward the surface through the overlapping surfaces of the Ligurian units.

$\mathrm{CH}_{4}$ gas phase, always present in the springs, further facilitates the brines to rise and favour ionic exchange processes between clays and salty waters. As a result (fig. 7) the waters catch $\mathrm{Na}$ and release $\mathrm{Mg}$ and subordinately $\mathrm{Ca}$.

Although Bencini and Duchi (1980) found an interaction of the Porretta springs with soluble evaporitic deposits (see $\mathrm{Ca} / \mathrm{SO}_{4}{ }^{2-}$ ratio in fig. 8), the Puzzola1, Sale and Bove springs show a large increase in $\mathrm{Ca}$ concentration not balanced by the $\mathrm{SO}_{4}{ }^{2-}$ ions, which do not support the interpretation of Bencini and Duchi (1980). Furthermore, the waters are undersaturated with respect to the minerals anhydrite, gypsum, and halite (table III), confirming that the waters do not emerge from evaporitic rocks. The Dolomite saturation index approaches zero showing the occurrence of equi- 


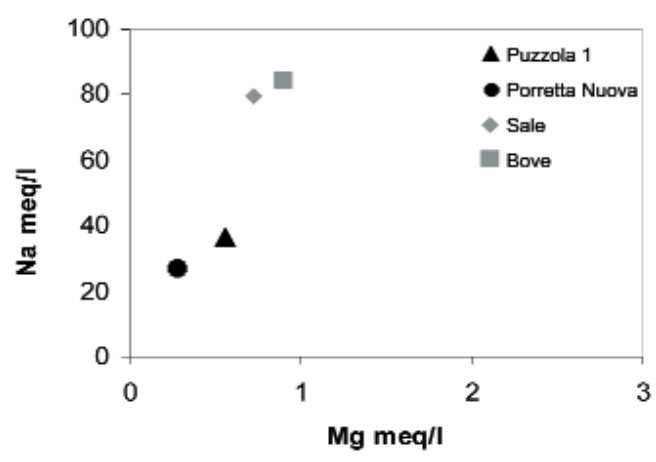

Fig. 7. meq/l $\mathrm{Na}$ versus meq/l $\mathrm{Mg}$ diagram. The values for the sampled thermal springs show a high $\mathrm{Na}$ content suggesting an interaction with Na-rich clay minerals.

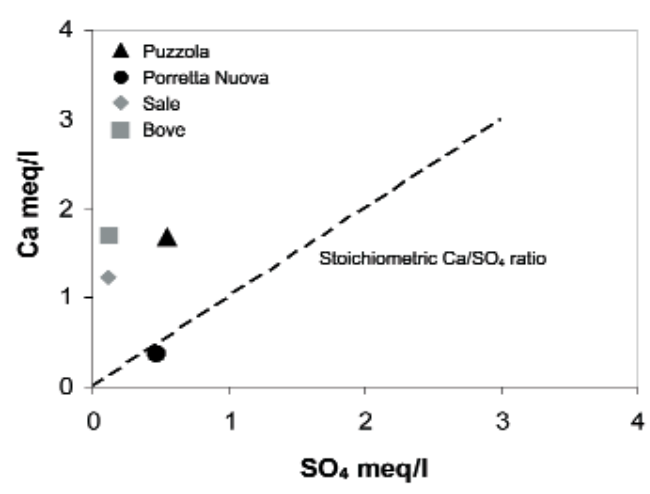

Fig. 8. Ca versus $\mathrm{SO}_{4}$ contents for the collected water samples showing a clear $\mathrm{Ca}$ enrichment.Only Porretta Nuova falls on the stoichiometric $\mathrm{Ca} / \mathrm{SO}_{4}$ ratio line.

librium with dolomitic rocks for water circulating at relatively shallow levels. During their uprising towards the surface, they mix with waters of deeper origin (brines) hosted in Pliocene sediments thus reaching their final $\mathrm{Na}-\mathrm{Cl}$ connotation.

\subsection{Chemical and isotopic features of dissolved and venting gas}

The chemical composition of the gas phase of both bubbling and dissolved gases is displayed in table II. The dissolved gases exhibit a
$\mathrm{CH}_{4}$ amount up to five orders of magnitude higher than that of air saturated water. The $\mathrm{N}_{2-}$ $\mathrm{CO}_{2}-\mathrm{CH}_{4}$ diagram (fig. 9) displays the chemical composition of the bubbling gases collected at Porretta Nuova and Sale springs, besides the chemical composition of the dissolved gases

Table III. Saturation indexes (SI) calculated for the main mineralogical phases in equilibrium with the thermal waters. It is evident how aragonite and calcite are close to the saturation showing the attainment of the equilibrium for the less saline waters (Puzzola 1 and Porretta Nuova, new thermal plant), while more concentrated waters (Sale and Bove, old thermal plant) are equilibrated with calcite and dolomite. SI calculated by the WATEQP software (Appelo, 1988) and expressed as the logarithm of the ion activity ratio pertinent to a mineralogical phase, and the equilibrium constant of its solubility product.

\begin{tabular}{ccccc}
\hline \hline Phase & Puzzola 1 & Porretta Nuova & Sale & Bove \\
\hline Anhydrite & -3 & -3.6 & -3.98 & -3.86 \\
Aragonite & 0.03 & -0.34 & -0.13 & 0.04 \\
Calcite & 0.17 & -0.2 & 0.01 & 0.18 \\
Dolomite & -0.04 & -0.34 & 0.04 & 0.32 \\
Fluorite & -0.6 & -1.24 & -0.7 & -0.64 \\
Gypsum & -2.77 & -3.4 & -3.82 & -3.69 \\
Halite & -4.7 & -5.05 & -4.07 & -4.05 \\
\hline
\end{tabular}

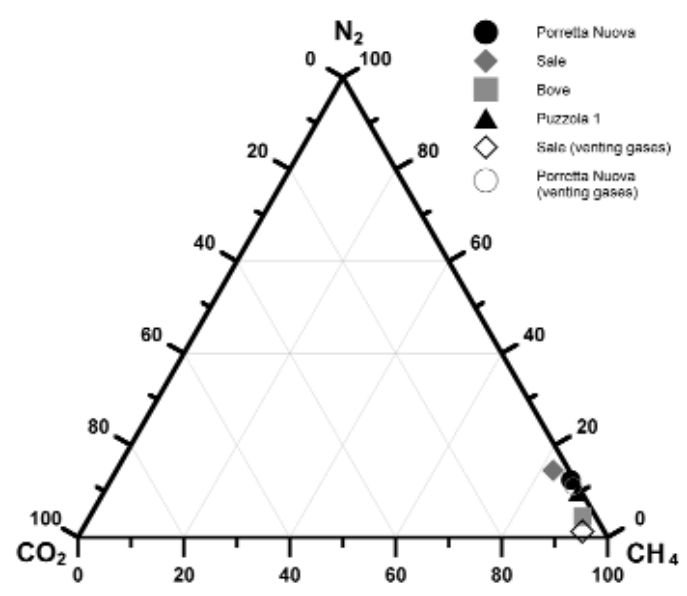

Fig. 9. $\mathrm{N}_{2}-\mathrm{CO}_{2}-\mathrm{CH}_{4}$ diagram showing a $\mathrm{CH}_{4}$-dominated gas phase for both dissolved and bubbling gases. 


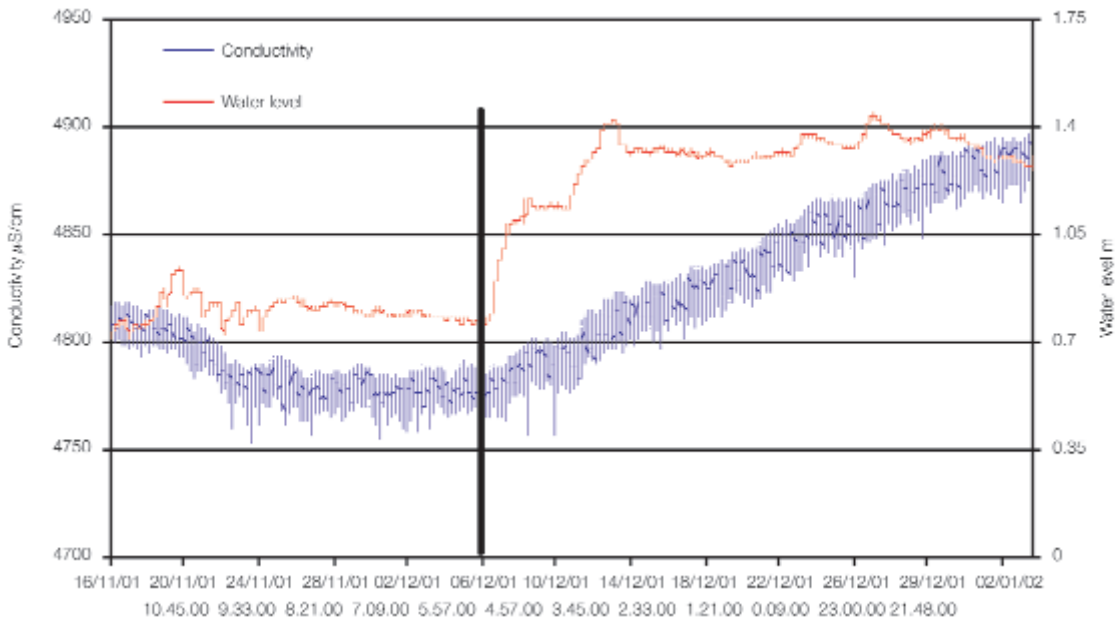

Fig. 10. Temporal variations of conductivity and water level at the Puzzola spring recorded during November 2001-January 2002. The vertical black line marks the $M_{d}=3.1$ seismic event that occurred on December 6, 2001.

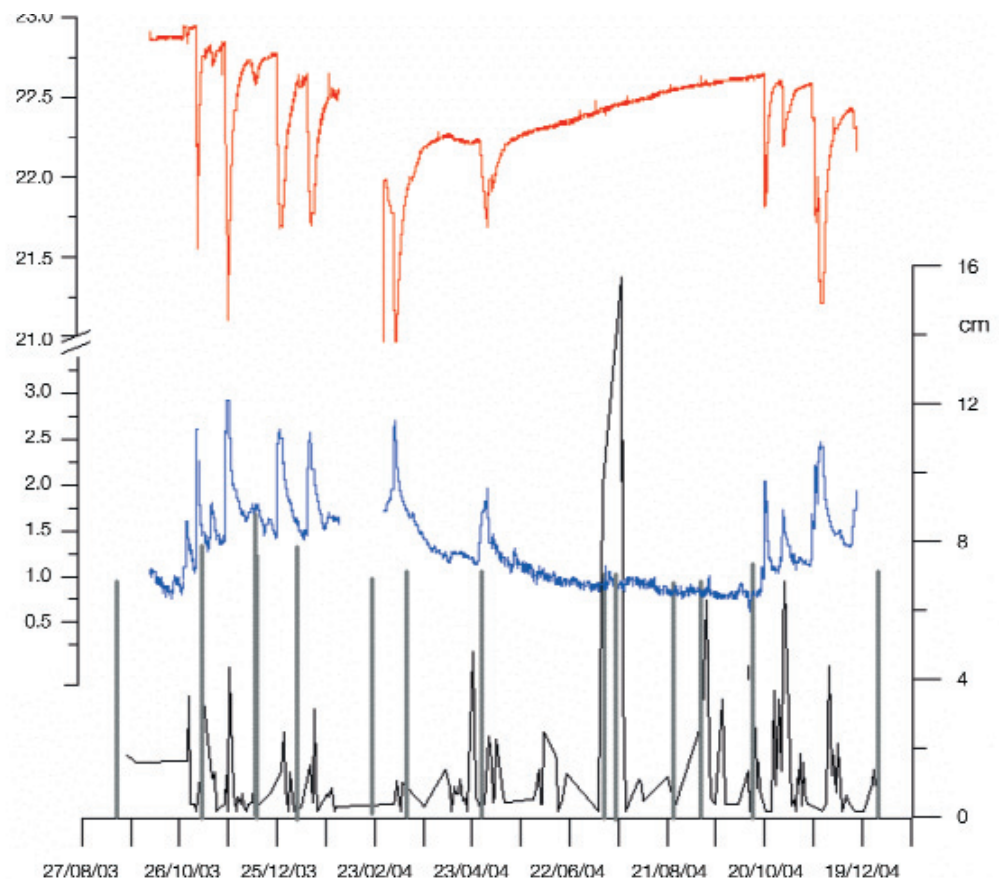

Fig. 11. Temporal variations in water temperature $\left(21-23^{\circ} \mathrm{C}\right)$ and water level $(0.5-3 \mathrm{~m})$ in the Puzzola spring from August 2003 to February 2005. The earthquakes that occurred within a $20 \mathrm{~km}$-radius area centered on Porretta Terme town are shown as vertical grey lines. The rainfalls are reported as daily mean value for the entire monitoring period $(0-16 \mathrm{~cm})$. The rain-gauge is located close to the Porretta thermal center. 
collected at all the sampling sites. The graph exhibits their very similar composition. The He concentration measured in the free gas collected at Porretta nuova spring is distinctly higher than the atmosphere. On the other hand the high $\mathrm{He} / \mathrm{Ne}$ ratio highlights a negligible atmospheric contribution. The isotopic He composition as low as $0.04 \mathrm{R} / \mathrm{Ra}$, reveals a clear radiogenic signature. This information rules out any release of mantle-derived components over the study area. According to carbon and hydrogen isotopic data of gases collected over the Emiliano Appennine (Duchi et al., 2005), the $\mathrm{CH}_{4}$ gas phase would represent the extreme stadium of the thermal degradation of organic substance trapped in the sediments.

\subsection{Long-term automatic monitoring}

During the 2001-2004 observation period many variations in the water level and conductivity were recorded (figs. 10-11). The data were analyzed besides the shocks occurred over a $20 \mathrm{~km}$ radius area (table IV). A slight anomaly in conductivity and water level at the «Puzzola 1»

Table IV. $M_{d} \geq 1.8$ seismic events within a $20 \mathrm{~km}$-radius area centered on Porretta Terme town during the 20012006 observation period.

\begin{tabular}{cccc|cccc}
\hline \hline Date & Latitude & Longitude & Magnitude & Date & Latitude & Longitude & Magnitude \\
\hline $06 / 12 / 2001$ & 44.091 & 11.076 & 3.1 & $06 / 11 / 2003$ & 44.389 & 10.628 & 2.9 \\
$08 / 06 / 2002$ & 44.274 & 10.618 & 4 & $11 / 12 / 2003$ & 44.326 & 11.055 & 3.2 \\
$09 / 06 / 2002$ & 44.386 & 10.692 & 2.5 & $12 / 12 / 2003$ & 44.288 & 11.019 & 2.8 \\
$11 / 06 / 2002$ & 44.395 & 10.693 & 2.6 & $13 / 12 / 2003$ & 44.297 & 11.038 & 2.8 \\
$13 / 06 / 2002$ & 44.391 & 10.692 & 2.7 & $04 / 01 / 2004$ & 44.273 & 10.946 & 2.9 \\
$18 / 06 / 2002$ & 44.396 & 10.683 & 4.2 & $05 / 01 / 2004$ & 44.169 & 10.783 & 2.5 \\
$05 / 07 / 2002$ & 44.396 & 10.702 & 3.1 & $23 / 02 / 2004$ & 44.396 & 10.789 & 2.5 \\
$08 / 07 / 2002$ & 44.386 & 10.711 & 2.7 & $16 / 03 / 2004$ & 44.248 & 10.959 & 2.6 \\
$09 / 07 / 2002$ & 44.397 & 10.696 & 3.3 & $04 / 05 / 2004$ & 44.295 & 10.957 & 2.6 \\
$13 / 08 / 2002$ & 44.396 & 10.689 & 2.5 & $10 / 06 / 2004$ & 44.021 & 11.002 & 2.1 \\
$06 / 09 / 2002$ & 44.063 & 11.286 & 2.5 & $22 / 07 / 2004$ & 44.258 & 11.076 & 1.9 \\
$11 / 10 / 2002$ & 44.397 & 10.688 & 2.7 & $23 / 07 / 2004$ & 44.155 & 10.820 & 2.6 \\
$18 / 11 / 2002$ & 44.221 & 10.778 & 2.5 & $30 / 07 / 2004$ & 44.221 & 10.620 & 2.6 \\
$10 / 02 / 2003$ & 44.137 & 10.812 & 2.5 & $22 / 08 / 2004$ & 44.349 & 10.738 & 2.5 \\
$30 / 03 / 2003$ & 44.256 & 10.793 & 2.5 & $10 / 09 / 2004$ & 44.277 & 10.738 & 2.5 \\
$06 / 04 / 2003$ & 44.291 & 10.981 & 2.7 & $09 / 10 / 2004$ & 44.352 & 10.828 & 2.7 \\
$06 / 04 / 2003$ & 44.266 & 10.987 & 3 & $26 / 12 / 2004$ & 44.046 & 11.109 & 2.6 \\
$07 / 04 / 2003$ & 44.306 & 10.991 & 2.7 & $11 / 01 / 2005$ & 44.092 & 10.823 & 1.8 \\
$11 / 04 / 2003$ & 44.264 & 10.982 & 2.6 & $01 / 03 / 2005$ & 44.272 & 11.080 & 2.2 \\
$11 / 04 / 2003$ & 44.268 & 10.970 & 2.7 & $29 / 01 / 2006$ & 44.324 & 11.409 & 2.0 \\
$21 / 04 / 2003$ & 44.324 & 10.701 & 2.5 & $02 / 02 / 2006$ & 44.239 & 11.470 & 2.0 \\
$24 / 04 / 2003$ & 44.268 & 10.965 & 2.7 & $05 / 02 / 2006$ & 44.301 & 11.491 & 2 \\
$01 / 06 / 2003$ & 44.344 & 10.708 & 2.6 & $03 / 04 / 2006$ & 44.155 & 11.393 & 2 \\
$11 / 07 / 2003$ & 44.376 & 10.606 & 2.7 & $05 / 06 / 2006$ & 44.259 & 11.275 & 2 \\
$04 / 08 / 2003$ & 43.978 & 10.991 & 2.5 & $17 / 08 / 2006$ & 44.282 & 11.550 & 2 \\
$18 / 08 / 2003$ & 44.362 & 10.749 & 2.9 & $21 / 06 / 2006$ & 44.319 & 11.451 & 2 \\
$18 / 08 / 2003$ & 44.364 & 10.717 & 2.5 & $14 / 06 / 2006$ & 44.272 & 11.449 & 2 \\
$18 / 08 / 2003$ & 44.379 & 10.723 & 2.8 & $21 / 11 / 2006$ & 44.200 & 11.580 & 2.0 \\
$15 / 09 / 2003$ & 43.936 & 11.299 & 2.5 & & & & \\
\hline & & & & & & \\
\hline
\end{tabular}


spring followed the seismic shock occurred on December 6th, 2001 lasting also as post-seismic effect (fig. 10), when the water level increased by a factor of two. After two months, in January 2002, the continuous monitoring stopped, however the physico-chemical parameters were still above the pre-seismic values. The trend shown by the electric conductivity might highlight that higher values than those previously measured lasted for a long time span after the seismic shock as a consequence of a slow deformation process as already observed along the Apennines Chain (Italiano et al., 2004). The increases in the water level observed in 2003 at the «Puzzola 1» site, (when the continuous monitoring had started again) were accompanied by sharp temperature drops probably due to changes in the mixing proportions between a shallow cold water component and a deeper thermal one. Figure 11 displays that the above-mentioned modifications have occurred coinciding to other natural phenomena: seismicity and rainfalls. Both of them are well

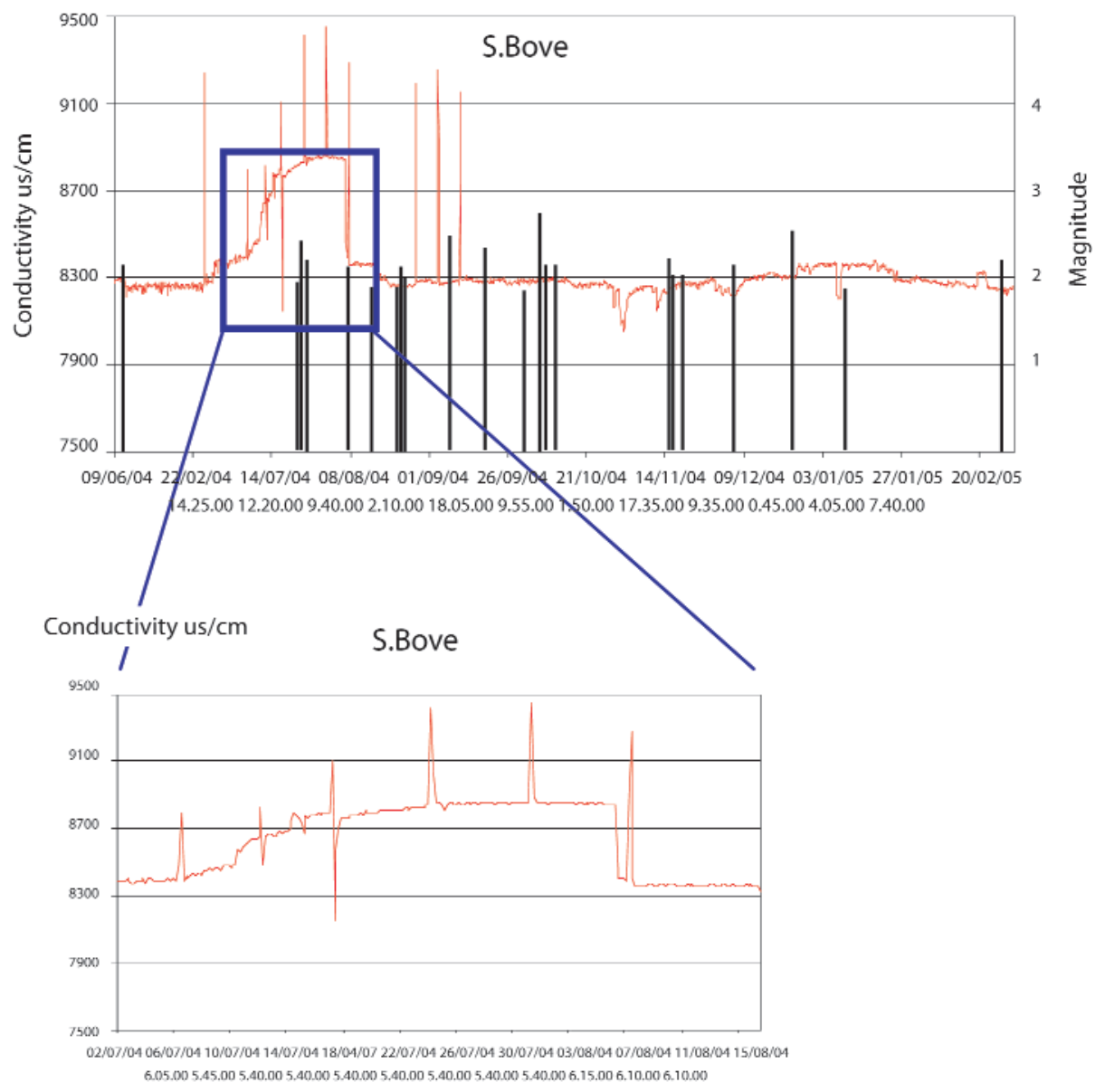

Fig. 12. Temporal variations in conductivity at the Bove spring during June 2004-February 2005 observative interval. The earthquakes occurred within a $20 \mathrm{~km}$-radius area centered on Porretta Terme town are shown as vertical black lines. Only the July 2004 shocks caused temporary modifications in the electrical conductivity. The recorded spikes are a consequence of the «anthropic disturbances» due to chlorine addition to the water. 
known to be able to induce modifications on the groundwaters, however, the absence of carstic systems in the area does not allow fast water circulation that, on the other hand, can be enhanced by the opening of microfractures due to seismic shocks. As a matter of fact, the collected data make it hard to discriminate which, between seismicity and rainfall, is responsible for the observed modifications. A possible model can be as follows: a long-term deformation process is active along that sector of the Apennines Chain; sometimes ruptures occur generating shocks of generally low magnitude; the intrusion of rain water along the fault lines acts as a lubricant and allows small movements of the fault planes under stress accumulation. The concomitant occurrence of low-energy seimic events, rainfalls and modifications to the mixing proportions of different water bodies is the consequence of a complex.

These observations stress the role of fault movement on the mixing ratios changes at depth that can modify, for example, the electrical conductivity without changes in the water temperature. Coinciding with the shocks in June and Ju-

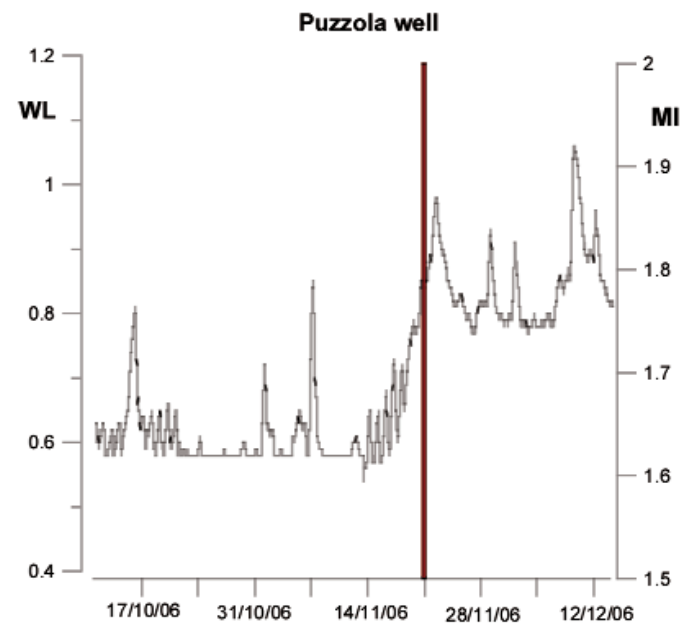

Fig. 13. Temporal variations of the water level at the Bove spring during October-December 2006 observative interval. One earthquake occurred within a 20 km-radius area, however because of the low energy is not considered as responsible for the observed modifications (see text). ly 2004 respectively, we observed a slight water level increase not associated with any temperature variation. The same shocks induced modifications at the Bove site (fig. 12) where the following macroscopic observations fit with the recorded data: i) an anomalous gas bubbling activity was observed inside the Bove spring from the beginning of June 2004; ii) the electrical conductivity probe recorded a variation that increased the background value from less than 8300 to about $9000 \mu \mathrm{S}$. Such a variation, which lasted more than a month, started about one month before the seismic sequence of July 2230th, when the electrical conductivity reached its maximum value. Similar behavior was never observed even when earthquakes with equivalent magnitudes occurred around Porretta. The modifications recorded during the 2006 monitoring period highlighted how deformation can be considered responsible for geochemical modifications in the absence of seismic activity. Although the variation in the water level (from 60 to more than $80 \mathrm{~cm}$ ) started together with the low-energy shock which occurred on 21st November 2006 (fig. 13), it is hard to accept that a low-energy shock which occurred $20 \mathrm{~km}$ away from the observation site induced similar modifications to the groundwater circulation. However, following the above mentioned model, the deformative effect may be responsible for the observed phenomena as the low energy shock was a rupture episode that occurred at a distance but was generated by the same Apennines deformative activity.

\section{Conclusions}

The thermal springs of Porretta represent an interesting study site to better understand the relation between fluids and seismogenic structures. In this sense the results we obtained are of general interest even though the study area is small and of local interest.

The discharged thermal waters are fed by meteoric waters which reached saturation with carbonatic rocks, mixed to brines coming from Pliocene sediments. A methane-dominated gas phase is dissolved at all the thermal springs that sometimes become gas-oversaturated. 
The temporal variations of the geochemical features of both gas and thermal waters were not investigated (e.g., by a monthly sampling) but long-term continuous monitoring investigated water temperature, electrical conductivity and water level even though with much datamissing (Greenspan probes from 2001 to 2006). The interpretation of the geochemical variations highlights the importance of the fluid monitoring in a seismogenetic structure. Some of the recorded modifications occurred in concomitance with both earthquakes located on the tectonic lineament crossing the town of Porretta, and rainfalls. The model we propose interprets the modifications of the water composition as a consequence of local stress accumulation, where the infiltrating rain water allows local fault-planes under stress to slide generating low-magnitude earthquakes. The obtained results are in full agreement with previous observations showing how geochemical modification to the circulating fluids can be induced by crustal deformation besides crustal ruptures (earthquakes). As a consequence, the seismogenic behaviour of a tectonic line can be recognized from the modifications occurring to the uprising fluids due to local stress accumulation.

\section{Acknowledgements}

The authors thank H. Woith and F. Yang whose criticisms and suggestions greatly improved the paper. The research work was supported by the Grant IMONT-2002 «Monitoraggio chimico-fisico e valutazione delle possibili correlazioni con eventi sismici in alcune sorgenti idrotermali dell'Appennino Tosco Emiliano Romagnolo: approcci innovativi per la valutazione delle caratteristiche di permeabilità degli acquiferi» and by the project «Gestione idrogeologica e monitoraggio ambientale delle acque termominarali Porrettane».

\section{REFERENCES}

Albarello, D., G. Ferrari, G. Martinelli and M. MucCIARELLI (1991): Well-level variation as a possible seismic precursor: a statistical assessment from Italian historical data, Tectonophysics, 193, 385-395.
APPELO, C.A.J. (1988): WATEQP Program, Institut voor Aardwetenschappen, Vrije Universiteit, Amsterdam.

Bencini, A. and V. Duchi (1980): Studio geochimico su alcune acque di Porretta Terme Bologna (Italia), Atti Soc. Tosc. Sci. Nat., Mem., Serie A, 87, 365-374.

Bierma, R., M.C. Eppes and F.J. Pazzaglia (2005): Evidence for late quaternary faulting in the Reno river valley, Northern Apennines mountains, Italy, Geol. Soc. Am., Abstr. Programs, 37 (7), pp. 431.

Capasso, G. and S. Inguaggiato (1998): A simple method for the determination of dissolved gas in natural waters. An application to thermal waters from Vulcano Island, Appl. Geochem., 13 (5), 631-642.

CAPPoni, P. (1608): Libro della Medicina delle acque Porrettane diviso in cinque trattati, Manuscript no. 1260 , Biblioteca Comunale dell' Archiginnasio, Bologna.

Castello, B., G. Selvaggi, C. Chiarabba and A. Amato (2005): CSI Catalogo della Sismicità Italiana 19812002, versione 1.0. (INGV-CNT, Roma).

Chiaraluce, l., A. Amato, M. Cocco, C. Chiarabba, G. Selvaggi, M. Di Bona, D. Piccini, A Deschamps, L. Margheriti, F. Courboulex and M. RipPe (2004): Complex normal faulting in the Apennines thrust-andfold belt: the 1997 seismic sequence in Central Italy, Bull. Seismol. Soc. Am., 94, 99-116.

Ciancabilla, N., G.C. Borgia, R. Bruni, F. Ciancabilla, S. PALMIERi and L. VICARI (2004): Le sorgenti dell'Alta valle del Reno (Appennino Bolognese): nuovi elementi per approfondire la genesi dei movimenti gravitativi profondi nei terreni argillitici caoticizzati dell'appennino Tosco-Emiliano, Il Geologo dell'Emilia-Romagna, 18, 5-14.

DE Rossi, M.S. (1875): Quadro generale statistico topografico giornaliero dei terremoti avvenuti in Italia nell'anno meteorico 1874 col computo di alcuni altri fenomeni, Atti Acc. Pont. Nuovi Lincei, 28, 514-536.

Duchi, V., G. Venturelli, I. Boccasavia, F. Bonicolini, C. Ferrari and D. Poli (2005): Studio geochimico dei fluidi dell'Appennino Tosco-Emiliano-Romagnolo, Boll. Soc. Geol. It., 124, 475-491.

EPSTEIn, S. and T. MAYEdA (1953): Variation of ${ }^{18} \mathrm{O}$ content of water from natural sources, Geochim. Cosmochim. Acta, 4, 213-224.

FACCI, M., A. GuidAnTI and R. ZAGnONI (1995): Le Terme di Porretta nella Storia e nella Medicina (Nuèter editions), vol. 2, pp. 649.

Hunstad, I., G. Selvaggi, N. D’Agostino, P. England, P. Clarke and M. PIEROzZI (2003): Geodetic strain in peninsular Italy between 1875 and 2001, Geophys. Res. Lett., 30 (1181), doi: 10.1029/2002GL016447.

Italiano, F., G. Martinelli and A. Rizzo (2004): Seismogenic-induced variations in the dissolved gases of the thermal waters of the Umbria region (Central Apennines, Italy) during and after the 1997-98 seismic swarm, Geochem. Geophys. Geosyst., 5 (11), Q11001, doi: 10.1029/2004GC000720.

Kendall, C. and T.B. Coplen (1985): Multisample conversion of water to hydrogen by zinc for stable isotope determination, Anal. Chem., 57, 1437-1440.

LorenzINI, D. (1898): Guida dei Bagni della Porretta e Dintorni, Bologna, pp. 167.

Minissale, A., G. Magro, G. Martinelli, O. Vaselli and G.F. TASSI (2000): A fluid geochemical transect in the 
Northern Apennines (central-northern Italy): fluid genesis and migration and tectonic implications, Tectonophysics, 319, 199-222.

Montone, P., M.T. Mariucci, S. Pondrelli and A. Amato (2004): An improved stress map for Italy and surrounding regions (Central Mediterranean), J. Geophys. Res., 109, B10410, doi: 10.1029/2003JB002703.

NANNI, T. and G.M. ZuPPI (1986): Acque salate e circolazione profonda in relazione all'assetto strutturale del fronte adriatico e padano dell'Appennino, Mem. Soc. Geol. It., 35, 979-986.

Piccinini, D., C. ChiarabBa, P. Augliera and The Monghi-
DORO EARTHQUAKE GROUP (2006): Compression along the Northern Apennines: evidence from the $M_{w} 5.3$ Monghidoro earthquake, Terra Nova, 18, 89-94.

Piombo, A., G. Martinelli and M. Dragoni (2005): Postseismic fluid flow and Coulomb stress changes in a poroelastic medium, Geophys. J. Int., 162, 507-515.

Schoeller, H. (1955a): Geochemie des Eaux Souterraines, Masson.

Schoeller, H. (1955b): Le Eaux Souterraines, Masson.

SEISMIC BuLLETIN (2007): INGV-CNT seismic bulletin (available on line at: http://www.ingv.it/ roma/reti/rms/ bollettino/). 